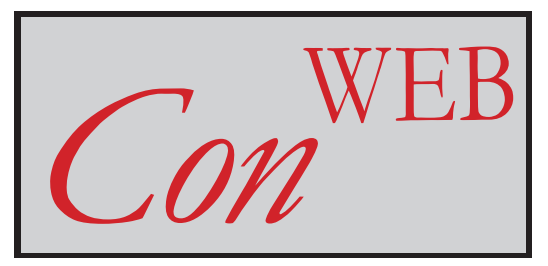

Webpapers on

Constitutionalism \& Governance beyond the State

Year 2002 | No 6

Pathos and Patina: The Failure and Promise of Constitutionalism in the European Imagination

Ulrich Haltern, Humboldt University, Faculty of Law, Berlin

ISSN: 1756-7556

conWEB - webpapers on Constitutionalism and Governance beyond the State www.bath.ac.uk/esml/conWEB 


\title{
Pathos and Patina: The Failure and Promise of Constitutionalism in the European Imagination
}

\author{
Ulrich Haltern, Humboldt University, Faculty of Law, Berlin *
}

\begin{abstract}
Legal studies react to the Union's social legitimacy deficit either by funneling the problem into empirical sociology (accompanied by the familiar call for more transparency and democracy), or by ignoring it altogether. This article argues that the crisis in social acceptance can be traced back to the texture of EU law. Law is more than a body of rules: It is a social practice, a structure of meaning, and a system of beliefs. In this light, national law has a richly textured cushion of cultural resources to rely on, which makes it "ours". In contrast, EU law embodies the fluid surface of consumer identity and appears less "ours". The Union's counter-measures - adding pathos and patina to neutralize our distrust - have proven unsuccessful. The way out, then, is coming to terms with the market citizen, rather than believing in, and forcing upon the consumer, stories of shared values and historically situated commonality.
\end{abstract}

\section{Constitutionalism's Never-Ending Legitimacy Crisis}

European constitutionalism used to be all the rage, but isn't any longer. Scores of articles and books take it for granted. If they bother making explicit mention of it at all, it is in the self-assured way of statements such as "Constitutionalism is the DOS or Windows of the European Community." What's more important, the European Court of Justice makes no bones about its understanding of the Treaties as the Constitution of the Union. As early as 1964, in Costa v. ENEL, the Court referred to the EEC Treaty as being "in contrast with international treaties". ${ }^{2}$ Fifteen years ago in Les Verts, it unabashedly called the Treaty "the basic constitutional charter". ${ }^{3}$ In its opinion on the Draft agreement on a European Economic Area, the Court eventually held that

* Special thanks to Antje Wiener and Colin Harvey. This paper was first presented at the third meeting of the UACES Study Group on Constitutionalism and Governance Beyond the State, Belfast, February 2002.

${ }^{1}$ This is the opening line in J.H.H. Weiler's The Reformation of European Constitutionalism, 35 JCMS 97 (1997), at 97.

${ }^{2}$ Case 6/64 [1964] ECR 585, 593.

${ }^{3}$ Case 294/83 [1986] ECR 1339, 1365. 
the EEC Treaty, albeit concluded in the form of an international agreement, none the less constitutes the constitutional charter of a Community based on the rule of law. As the Court of Justice has consistently held, the Community treaties established a new legal order for the benefit of which the states have limited their sovereign rights, in ever wider fields, and the subjects of which comprise not only Member States but also their nationals... The essential characteristics of the Community legal order which has thus been established are in particular its primacy over the law of the Member States and the direct effect of a whole series of provisions which are applicable to their nationals and to the Member States themselves. $^{4}$

The story of the Community's "constitutionalization" has been told way too often to be repeated here. Suffice it to mention the foundational period's doctrines of direct effect, of supremacy, of preemption, and of implied powers, the Court's protection of human rights, and the elaborate Community system of judicial review. ${ }^{5}$ Thus, the Community legal order has evolved from a set of legal arrangements binding upon sovereign states into a vertically integrated legal regime conferring judicially enforceable rights and obligations on all legal persons and entities, public and private, within the sphere of application of EC law. That, exactly, is the definition of what is called "constitutionalization". 6

The process of constitutionalization has been accompanied by a handful of mysteries, none of them very mysterious any more. Why, for example, would the Member States agree to, or at least acquiesce in, such a profound transformation of the Community system - something that many called a judicial rewriting of the Treaties? ${ }^{7}$ Why, to give another example, would the Member State courts willingly go along and let themselves be persuaded and co-opted, despite the radicalism of the ECJ's doctrinal construct?

Those riddles have largely been solved, with illuminating accounts and insightful explanations provided by a number of studies. ${ }^{8}$ While there is little reason for complacency, it is now safe to assume the constitutionalization thesis will not be brought down by any of those mysteries. It all fits too

\footnotetext{
${ }^{4}$ Opinion 1/91 [1991] ECR I-6084, 6102.

5 The classic account being, of course, J.H.H. Weiler, The Transformation of Europe, 100 YALE L.J. 2403 (1991). Reprinted in J.H.H. Weiler, The Constitution of Europe. "Do the New Clothes Have AN EMPEROR?” AND OTHER ESSAYS ON EUROPEAN INTEGRATION (Cambridge/Engl:: Cambridge UP 1999), 10. References point to this latter source.

${ }^{6}$ Alec Stone Sweet, Constitutional Dialogues in the European Community, in: THE EuROPEAN COURTS AND National Courts: Doctrine And Jurisprudence (Anne-Marie Slaughter, Alec Stone Sweet \& Joseph H. H. Weiler eds.) (Oxford: Hart Publ. 1998), 305, at 306.

7 Hartley goes so far as to call it a de facto amendment of the Treaties by the Court. T.C. HARTLEY, Constitutional Problems of the European Union (Oxford: Hart Publ. 1999), 131.

${ }^{8}$ Weiler, Stone, Slaughter/Mattli, Craig/de Búrca.
} 
neatly. The few remaining champions of internationalism - who call into question the constitutionalization thesis and argue that EC law is, at the end of the day, not all that different from classical international law - meet with fierce, persuasive, and indeed cogent, responses from the constitutionalization thesis crowd. ${ }^{9}$

So why bother writing, again, about European constitutionalism? Isn't that like writing about judicial review in the U.S., where so much has been said and done about the subject that student editors have a hard time keeping their eyes open when obliged to read just another manuscript on the matter?

Unlike the tired old judicial review debate, however, Europe's constitutionalism debate has, I believe, not even reached the heart of the matter. Part of it may be the confusion about what "constitutionalism" means. Take Professor Craig's essay on European constitutionalism in a recent issue of the European Law Journal, which suggests no less than five different meanings of "constitutionalism" and "constitutionalization". ${ }^{10}$ To be sure, it is important to be clear about one's object of inquiry. But there is no need to stress that point since it is virtually impossible to find a statement on European constitutionalism without an elaborate definition of the term. It is, on the contrary, the excessive backing of normative assertions with burdensome abstract constitutional theory that sometimes makes you long for minimalism in the Sunsteinian sense: shallow incompletely theorized agreements which stay away from ambitious reasoning on the foundations of philosophical questions operating at a high level of abstraction. ${ }^{11}$

In notable contrast to this weighty foundationalist baggage, the burgeoning literature often seems to beg the hard questions. Why is it that the Union citizens are all but completely uninterested in "their" Union? How come that, according to the Commission itself, "many Europeans feel alienated from the Union's work"? Why is it that there is a "widening gulf between the EU and the people it serves"? Why do citizens "no longer trust the complex system to deliver what they want"? ${ }^{12}$ Craig reminds us that we must construct an appropriate normative foundation for the European legal order. Such an undertaking is, however, all too often bracketed in contributions to EU constitutional theory, mostly under the flag "Space precludes discussion of this issue." 13 The reason may be that legitimacy and illegitimacy are notoriously elusive concepts, sometimes dismissed as

${ }^{9}$ See poor Trevor Hartley being nicely, but firmly demolished by Paul Craig, Constitutions, Constitutionalism, and the European Union, 7 EUR. L.J. 125 (2001), at 130-4.

${ }^{10}$ Craig (supra note 9), at 127-8.

11 Cass R. Sunstein, One Case at a Time. Judicial Minimalism on the Supreme Court (Cambridge/Mass.: Harvard UP 1999), 11-14; Cass R. Sunstein, Leaving Things Undecided, 110 HARV. L. REV. 4 (1996); Cass R. Sunstein, Incompletely Theorized Agreements, 108 HARV. L. REV. 1733 (1995); CASS R. SUNSTEIN, LEgAL REASONING AND POLITICAL CONFLICT (New York/Oxford: Oxford UP 1996).

${ }^{12}$ Commission, European Governance - A White Paper, COM(2001) 428 final, OJ 2001/C 287/01, at 5.

${ }^{13}$ Craig (supra note 9), at 134 note 52. 
suggestive, even speculative, rather than analytically rigorous. ${ }^{14}$ Many commentators have reacted by cutting the conceptual cake of legitimacy in a number of directions. One can, for example, distinguish between the social, normative, performance, regime, and polity dimensions of legitimacy. ${ }^{15}$ Whether or not there is broad social acceptance of the system would be a question of social legitimacy then. That is a matter, it may seem, best left to empirical studies (like the one recently conducted by OPTEM for the European Commission ${ }^{16}$ ) and their interpretation by trained empirical sociologists. ${ }^{17}$ Although we lawyers worry about things like social rejection - Germany's lawyers had to learn the hard way in the Weimar Republic we certainly don't feel competent to make inquiries into peoples' beliefs and their consequences. What we're good at is formal, or legal, legitimacy. Formal legitimacy implies that all requirements of the law are observed in the creation of the institution of system. It is something akin to formal validity. ${ }^{18}$ That is, presumably, why the literature is overflowing with accounts of legal doubts about juridical constructs and democratic deficiencies, while the subject of social legitimacy leaves legal commentators mostly stunned and analytically silent. Usually, we voice our worries about social skepticism, thus making our bows in passing to empirical sociology and the cheeky but often penetrating and insightful feuilletons, and then hurry to funnel the debate into channels closer to home.

I will argue that such treatment of one of the core problems of European integration is inadequate. Social skepticism is, in fact, not the exclusive domain of empirical sociology. Rather, it is closely and, indeed, inseparably linked with the domain of law. Social legitimacy, then, is a matter of legal consideration, and deserves attention from the perspective of the law.

The law, as I shall argue, is not just a body of rules. It is a social practice, a way of being in the world. A social practice is not merely a set of prescribed actions, but rather a way of understanding self and others, and thus, a way to make actions meaningful. To live under the rule of law is to maintain a set of beliefs about the self and community, time and space, authority and representation. Law's rule is a system of beliefs - a structure of meaning within which we experience public order as the rule of law. Of course, there are other structures of meaning. Everything that can happen is within the imaginative reach of the rule of law. Yet, all that happens is

${ }^{14}$ J.H.H. Weiler, The European Court of Justice: Beyond Beyond Doctrine' or the Legitimacy Crisis of European Constitutionalism, in: THE EUROPEAN COURTS AND NATIONAL COURTS (supra note 6), 365, at 372-6.

15 Neil Walker, The White Paper in Constitutional Context, JEAN MONnET WORKING PAPER 10/01, http://www.jeanmonnetprogram.org/papers/01/011001.html.

${ }^{16}$ OPTEM S.A.R.L., Perceptions of the European Union. A Qualitative Study of the Public's Attitudes to and Expectations of the European Union in the 15 Member States and in 9 Candidate Countries, http://europa.eu.int/comm/governance/areas/studies/optem-report_en.pdf.

17 Such as, amongst many, PUBLIC OPINION AND INTERNATIONALIZED GOVERNANCE (Oskar Niedermayer \& Richard Sinnott eds.) (Oxford: Oxford UP 1995).

${ }^{18}$ WEILER (supra note 5), at 80. 
simultaneously imaginable in ways other than law. Most importantly, there are two alternative competing forms of meaning: political action and love. Their grammar is in many ways opposed to that of the rule of law, and each strives to suppress, or at least co-opt, the other. A cultural study of the rule of law must examine those alternative systems of meaning, just as law itself must recognize political action or love. ${ }^{19}$

Many things follow from such a cultural study of the law. The most important one in the present context, however, is that polity, constitution, and law are inextricably bound together. Let us take the state as an example. The state maintains itself through the 'invention' of a collective self that is the people. The people appears as both the sovereign and the product of the constitution. However, the project of state maintenance can succeed only because the state locates itself within an historical project that is both the source and the product of the state. Political communities construct the past of which they conceive themselves to be the product. The same is true of the territory of the state. In other words, the state invests, and maintains, meaning in a bounded space. Law, which is the source and the product of such imagination of political existence, and which serves as memory and storage of such political meaning, needs to be rooted in bounded principles, too. It carries forward constitutive meaning only if it goes beyond the rational, the efficient, or the just. That, however, is not the case in the European Union. If citizens don't give a hoot for the Union, that is because EU law isn't 'theirs'. EU law fails in its attempt to create and maintain a collective identity. It does not carry forward rooted meaning. I will, in a moment, try and explain why. What is obvious even now, though, is that the Union isn't more complicated or more opaque than any state government. It is not a lack of transparency, even though that would allow us lawyers to delve into more deliberations about what we can do best, like set up new org-charts, or propose, again, to place the whole decision-making process on the internet. Rather, the reason for the curious and specifically European dilemma is that the Union texts are merely texts, and nothing more. They are not 'our' texts. They lack deep social meaning. In the EU, meaning must be constructed and maintained in different ways, namely by ceaseless political action. The myth of never-ending progression in the Union is a veil that hides the double failure of Union law. That failure consists of its inability to store meaning; also, it is impossible to retrieve meaning by reading and interpreting the Union's law. EU constitutionalism fails in the same way, for the same reasons. Whether or not a Convent, after due deliberation, writes up a text and calls it a "Constitution", makes little difference to what has just been said. That "constitution" would also be nothing but a text. Just as the

${ }^{19}$ This cultural approach to symbolic meaning goes back to Ernst Cassirer and Michel Foucault and has been developed most forcefully by PAUL W. KAHN, THE REIGN OF LAW. MARBURY V. MADISON AND THE CONSTRUCTION OF America (New Haven/London: Yale UP 1997); PAul W. Kahn, The CulturaL Study of Law. Reconstructing Legal Scholarship (Chicago/London: Chicago UP 1999); PAUl W. Kahn, Law AND Love. The Trials OF KING LEAR (New Haven/London: Yale UP 2000). 
ink on the Treaty of Nice has not dried yet, and already we turn away and talk about the post-Nice process, we would not wait for the ink on that "constitutional" document to dry before we would think about the next, and the next, and the next thing to do.

I will first explain the relation between law, constitution, and social meaning (II.). Law is a way of perceiving the meaning of political events, but it is just one way. The political imagination is contested domain. To see an event as an instance of law's rule is to suppress alternative perceptions of the same event. One of those alternatives is political action. It is "law's other" and deploys a very different grammar. The conflict between law and political action (especially political action's apotheosis, revolution) is a conflict between past and future, tradition and possibility. It reaches its deepest expression in the tension between loyalty and responsibility. To understand the rule of law, we must look to the experience of the political as it makes conflicting claims of loyalty and responsibility. Most obviously, the tension arises at law's origin. The transition from revolution to law is the problem of creating a political order in which self-consciously novel action is displaced by legal permanence. That transition requires the production of a text - not just any text, but a text that bears the meaning of law's source. As it turns out, sacrifice becomes the crucial paradigm in this context. Sacrifice is the inscription on the body of an ideal meaning. More generally, sacrifice is the process by which ideas are embodied in historical artifacts. Law, then, begins with the act of reading the scarred body. Interpretation is the reverse process of inscription of meaning: it realizes the ideal content of the artifact. This is an old religious theme which links the meaning of the political under the rule of law to the meaning of the political in love's imagination. Law, if it is to carry forward meaning, cannot be explained by reason alone. It is here where liberalism fails.

I will then proceed to explain that EU law does not fulfill the criteria set out above (III.). The Union, born from the ashes of Auschwitz, millions dead and indescribable destruction, was the reaction to the destructive force of politics' eroticism. It is the spirit of reason that the Community rose from. The founders considered themselves to be men of the Enlightenment, and the task of creating an integrated Europe appeared to them to be a problem of applied political science. What informed the Community project (symbolized, mostly, in the Commission) was, and still is, the spirit of engineering. There is a total absence of sacrifice at the heart of the imagination of the political in Europe. Even if the founding ideas ever were backed by sacrifice, that never translated into the law. Therefore, while there is law (and the law, of course, is being followed), the law fails in carrying forward deep social meaning.

There has been no transition from political action to law, from future to past, from possibility to tradition, and from responsibility to loyalty. There couldn't be, in the face of the lack of storage for sacrifice. That explains Europe's breathlessness today, as well as the stunning lack of social 
legitimacy. As a consequence, we should stay away from the idea to write a "Constitution" for the Union.

However, that is not the end of the story. I am not trying to declare the end of the history of European integration (that would be laughable), nor have I much sympathy for theories prophesizing the decline of the West. I believe there is much promise where few people have been looking for it. Europe's potential lies precisely in its superficiality, in its privileging of the commercial, in its shallowness and emptiness. Many mourn this. Weiler, for instance, complains about European "bread and circus democracy" and a "Saatchi \& Saatchi Europe". ${ }^{20}$ However, there is strong evidence that today, "we can learn more about the operations and values of social communication

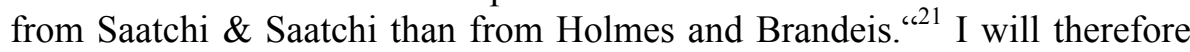
argue that the Union should forsake all striving for the nation-state's folklore and instead embrace the central ideology of "mainstream culture", which seems to be liberal consumerism (IV.). The hub of postmodern life strategy is not making identity stand, but the avoidance of being fixed and thus the fear of foreclosure of options. ${ }^{22}$ Doing just that by doing without a "constitution" would finally bring Europe closer to its citizens.

\section{The Meaning of a Constitution ${ }^{23}$}

The rule of law is a shorthand expression for the imaginative construction of a complete social-political order. It is a way of perceiving events and actors, and a framework of understanding that makes it possible to perceive legal meaning in every event. It provides a temporal and geographical shape to events, a normative grounds for claims of authority, and an understanding of the self and others as subjects with rights and responsibilities. ${ }^{24}$

The rule of law, then, is a social practice, a way of being in the world. To live under the rule of law is to maintain a set of beliefs about the self and community, and to understand actions of others and of the self as expressions of these beliefs. Functional analysis cannot grasp the meaning of law. It is the imagination that constructs the past and the future of the polity, just as it constructs, at the same time, the political identity of the citizen. In the political imagination of citizens of Germany, for instance, the rule of law echoes with the memory of World War II and Auschwitz; American citizens' political imagination of the rule of law echoes with the memory of revolution and civil war, with a continuity between the citizens and the

\footnotetext{
${ }^{20}$ J.H.H. Weiler, Bread and Circus: The State of the European Union, 4 ColuM. J. Eur. L. 223 (1998).

21 Ronald K.L. Collins \& David M. Skover, The Death of Discourse (Boulder, Colo.: Westview Press 1996), at 70.

22 Zygmunt Bauman, Tourists and Vagabonds: The Heroes and Victims of Postmodernity, in: ZYGMUNT BAuman, Postmodernity And ITS Discontents (New York: NYU Press 1997), at 89.

${ }^{23}$ In exploring the meaning of law and constitutions, I closely follow the arguments advanced by Paul Kahn (supra note 19).

${ }^{24}$ KAHN, LAW AND LOVE (supra note 19), at 171.
} 
Founders, etc. In other words, the rule of law is a structure of beliefs about the meaning of the polity. Its value lies not in objective facts but in the deployment of power to sustain these beliefs. What we must investigate, then, is the structure of meaning within our experience of public order as the rule of law occurs.

Perhaps, language is a useful analogy. Our ordinary understanding of the self is inseparable from our use of language. We belong to our language far more than it belongs to us, and through language we find ourselves participating in this particular history and society. What it means to be a subject is determined by a social phenomenon (language) that is itself contingent upon subjects who are shaped by it. Similarly, we are potential citizens of the state before we are anything else. We are not first individual subjects who then choose to join the polity. From the beginning, our imagination is shaped by a particular political and legal universe that claims us before we can claim otherwise. ${ }^{25}$

\section{Political Action as Law's Other}

The rule of law operates within the contested domain of the political imagination. It is one effort to structure political perception. Law, however, does not exhaust our perception of the political. There are conflicting appearances of political meaning. Like language, the rule of law is based upon a particular grammar. The alternative appearances of the political domain deploy different political grammars. Most importantly, there is political action - and revolution, being political action's apotheosis - which provides a very different structure for imagining the domain of the political. I will try and demonstrate the differences in the respective grammars of law on the one hand, and political action on the other, with regard to two issues only: time, and the individual.

Law's temporal structure is the construction of the future through the maintenance of past meanings. The rule of law contemplates only its own continuation. Therefore, we associate stability and predictability with it. Our belief in the rule of law rests upon the assumption that the future of the political order should be the same as its past. Law links the future to the past by continuing its permanence. When law comes into play, political meaning is already established, and law maintains it. Only the extraordinary can disturb law's rule which, essentially, is a maintenance project. Such extraordinary events may come from the outside in the form of invasion, or from inside the polity in the form of revolution.

Political events, however, can also be appreciated for the novelty they introduce. Political actors promise novelty and changes that will improve the political order. Such future-orientation becomes most evident in revolutions. Law and political action operate in diametrical temporal structure. The revolutionary project terminates the old and remakes the future. Political

\footnotetext{
${ }^{25}$ KAHN, REIGN OF LAW (supra note 19), at 35.
} 
action, in revolutionary moments, takes on a character completely ahistorical.

The rule of law is not the rule of men. It cannot be an expression of the will of some particular group or class (even if that group or class uses the law to pursue its ends). To explain a legal rule as a self-interested exercise of power by a group of individuals is to criticize the legitimacy of its claim to be law at all. Law's rule must appear to be the rule of no particular individual: the rule of law is the rule of no one. The independence of law from any particular subject accounts for many of the virtues associated with it, such as equality, impartiality, and universality. Law uses a variety of strategies to suppress the appearance of the individual subject - in Germany, for example, it is impossible, both for academics and judges, to use the first person singular.

In contrast, under the imagination of political action, politics is seen as a field for personal distinction, for great deeds and great words by the individual subject. The political actor seeks to perpetuate her memory by creating a singular appearance of the self. The goal of political action is not to maintain an already established legal order but the achievement of personal fame that can give shape to the future. Politics is subject-driven: the politician promises to be unique and will introduce new structures, programs, and ideas into the political order. Law appears merely as a sideconstraint, while the meaning of politics lies in the distinction of the self from others.

\section{Loyalty vs. Responsibility}

The conflict between law and political action (revolution) reaches its deepest expression in their opposing attitudes toward time. The revolutionary looks to the future, and sees the present as a means to a new or remade future. The past is valuable only insofar as it teaches something about the task of political reconstruction. The rule of law, on the other hand, looks to the past as the origin of the political meaning of the community. It sees the future as the space for the continuation of an already established order. The conflict between these two imaginations is mirrored by the distinctive moral stances that each perspective supports.

The rule of law claims loyalty as its source of moral support. Loyalty arises within particular, historically given situations. There can be no loyalty in the abstract. Nor is there a universal loyalty to all humankind. Loyalty attaches to the relationships within which I already find myself, not to those I might enter. Loyalty does not arise out of my plans for the future but from the past I already have, regardless of whether I was responsible for its creation. Obligations of loyalty can be created or deepened by consent, but they are not the same as obligations that arise from contract or promise. One can make promises to strangers, and break them without necessarily violating an obligation of loyalty (e.g., if one is willing to make up the damages). 
Revolution, on the other hand, finds support in the morality of responsibility. Responsibility is the moral stance that takes its fundamental orientation from the capacity to act and bring something new into being. It looks at the possible rather than the actual, and therefore moves toward a universal perspective. Revolution rejects the automatic privileging of the historical particular that characterizes loyalty. Rather, it is revolution's first task to precisely overcome the moral claims of loyalty. The rewriting of history, which now becomes a narrative of coercion by those who rule, undermines the pull of the past, and of loyalty. Breaking with the past opens a future constrained only by responsibility.

\section{The Transition from Revolution to Law}

Based on these insights, it becomes possible to identify the "meaning" (in Ernst Cassirer's sense) of law, and constitutions. While the imaginations of law and revolution compete, they do not succeed in suppressing each other as a whole. Sometimes they have to co-opt each other - most evidently at the point of law's origin. The problem of law's origin is to create a political order in which novel action is replaced by legal permanence. For revolution to give way to the rule of law, the political order must change its appearance. The virtue of loyalty must displace that of responsibility, a transition which is never easy.

To endure, a revolution requires a transition from the epiphanic moment to a stable order. Long after they have been experienced, revolutions must be read. Permanence requires establishing a historical memory.

Of course, there has to be a connection between the original event and the process of reading it. Germans remember and read the Hambacher Fest, not the American or French Revolution. ${ }^{26}$ It is not the abstract quality of an idea that infuses historical memory, but its quality as "ours". Memory and remembrance is not the same as studying political science.

The transition from revolution to law requires the production of a text for future generations. "The first generation writes the book of state; later generations read it," writes Paul Kahn. ${ }^{27}$ The text of the revolution is, for instance, the bodies of the revolutionaries themselves. Revolutions are, first of all, ideas. The abstract idea, however, becomes the foundation of a new political order only when individuals are willing to engage in acts of sacrifice and invest their bodies in that new set of ideas. Conversely, when citizens are no longer willing to sacrifice themselves to the existing order, it becomes an empty shell without the power to make a claim upon the citizen.

\footnotetext{
${ }^{26}$ See the pathbreaking work of PIERRE NORA, LIEUX DE MÉMOIRE, 4 Vols., Paris 1984-92; for an imitating German project see ETIENNE FrAnÇOIS \& HAgEN SCHUlze (EDS.), DeUTSCHE ERINNERUNGSORTE, 3 Vols., München: C.H. Beck 2001.

${ }^{27}$ KAHN, REIGN OF LAW (supra note 19), at 85.
} 


\section{The Role of Sacrifice}

The connection between the original event and the process of reading it is the sacrifice. A revolution belongs to a people because they carry forward its meaning in the sacrifices they have been willing to make. Sacrifice is the inscription on the body of ideal meaning. The scarred body is a visible symbol of the political meaning for which the individual is willing to give herself. Law, then, begins with the reading of the marked body. Sacrifice makes the body a text, a bearer of an authenticated testimony. If we are unwilling to make any sacrifice, we may not be anyone at all. We have no character, only desires. The desiring body is not read, it is satisfied. It leaves no trace; its very existence is a matter of indifference to others.

The body turns us from a focus on an indefinitely open future to the past we already have. It reminds us that we enter the political domain with a limited set of resources.

It is only a short step from reading the body to reading the constitution as the revolutionary text. The body is not infinite, but a rare resource. The finite and soon-to-disappear body-text needs to replaced by a text potentially infinite. The body lends the authenticity of its sacrifice to the text that is the product of revolution. In other words, the product of the spent body is the legal text. The sacrificed body establishes this text as ours.

The course of reasoning from revolution to law necessarily moves through the body, and from body to text. An idea becomes a legal text only through an act of sacrifice. Otherwise, it would be of no political significance. Law, then, is the text read out of past acts of political sacrifice. Sacrifice and interpretation are therefore linked. Sacrifice is the process by which ideas are embodied in historical artifacts - interpretation is the reverse process, by which the ideal content of the historical artifact is realized. It is loyalty that links interpretation to sacrifice: It directs interpretation to a particular sacrificial act that contains our meaning.

\section{The Failure of Liberalism}

No theory of contractual origins of law (whether or not behind a veil of ignorance) is capable of explaining why a particular system of law is uniquely ours. Efforts to explain or derive law's rule from the perspective of reason alone inevitably ignore the geographic and temporal boundaries that are at the core of our experience of the state.

Liberalism is speechless in the face of sacrifice. Liberalism sees justice at the heart of the modern political project; justice is the ambition of the constitutional project upon which every modern state is founded. Justice appears as the realization of reason in the legally protected relationships of individuals to each other and of each to the state. Hobbes set the pace: Justice expresses a kind of pure practical reason. Famously, this is the deployment of reason behind the "veil of ignorance". Reason promises the specification of just principles that are timeless and universal. Justice is blind because it measures conflicting claims against a universal metric of reason and ignores the identity or character of the person who makes the claims. 
Behind the veil of ignorance, there can be no pathologies (like uncontrolled individual desire or the communal pathology of the unreason of religion).

The rule of law, however, is different. Reason, and justice, are, of course, part of it. But it has also moved from contract to sacrifice. It is a maintenance project, writing forth the meaning of sacrifice as origin. Social contract theory cannot incorporate this. The liberal divide between public and private suppresses the erotic character of the political. This comes as no surprise because it has been a project of Enlightenment to understand politics as the product of reasoned discourse. An adequate conception of the political cannot start, or end, with justice. It is elementary for a political community to expect sacrifices from its members; in the state, this can be a question of life and death. The state conceives of itself as ultimate meaning and strives to perpetuate its own historical meaning over time. The state loves only itself. Political theory must be capable of explaining the conditions under which citizens are ready to bear the sacrifices expected from them. Justice, as explanation, is insufficient.

\section{The Failure of European Constitutionalism}

The meaning of law in the European Union is very different from the meaning I have just laid out. Union law lacks the erotic component so distinctive of the domain of the political in nation-states. It epitomizes the liberal project of a rational rule of law rather than that irrational, bounded, rooted project that is the nation-state rule of law. I will attempt to show that the differences in the conception of rule of law have decisive consequences for the Union's finality and future gestalt.

\section{The Union's Birth From Rationality}

No one will want to maintain that Europe was born from belief, visionary revolution, shared sacrifices, emotions, or love. If there is one project of political order that was born from the spirit of rationality and enlightenment, that would be the Union. How could it be otherwise? To be sure, there is a lot of talk to be heard about the Schuman Declaration's pathos; there is also recurring talk of Churchill's Zurich speech on September 19, 1946, calling for a "United States of Europe". ${ }^{28}$ However, Churchill had been removed from office at the time. What's more, it seems the Zurich speech was just another example of that typically British motto, "Don't do what I do, do what I tell you to do." ${ }^{29}$ It was Churchill himself who, a few years earlier,

${ }^{28}$ Winston S. Churchill, His Complete Speeches, 1897-1963, Vol. 7, 1943-1949 (ed. by Robert Rhodes James), Chelsea House Publishers, 1974; reprinted in Brent F. Nelsen/ Alexander C.-G. STubB (EDS.), The European Union. Readings on the Theory and Practice of European Integration, Boulder/London: Lynn Rienner, $2^{\text {nd }}$ ed. 1998, at 7.

${ }^{29}$ J.H.H. Weiler/Sybilla C. Fries, A Human Rights Policy for the European Community and Union: The Question of Competences, in: Philip Alston (ED.), The EU And Human Rights, Oxford: Oxford UP 1999, at 147 (147). 
had maintained that "We are with Europe, but not of it." ${ }^{30}$ Europe was a macabre unity, coming together in infinite destruction, with camps of POWs and millions dead, as an expanse of rubble. Auschwitz was the absolute zero, and the hatred was great enough to spawn serious suggestions to "strew Germany with salt". To build Europe upon emotional appeals to feelings of sharedness and community would necessarily have had to fail. Still, there were two imminent problems to solve: first, what to do with Germany, second, how to rebuild Europe? ${ }^{31}$ The Schuman plan was the well-planned and deliberate response to these questions. One should not be deceived by its pathos: note that it speaks of "de facto solidarity" only. The lack of grand vision, and the tangible pragmatism of the Declaration has been noted too often to be repeated here. What is important, though, is the fact that European integration was conceived as a contract and as a project guided by enlightened rationality. We see this in many details. Take the original gestalt the Union. There is no doubt that the Union, irrespective of its subsequent constitutionalization, was constructed through classic international law treaties. International law, with few exceptions, is basically law through consent between states. Governments represent states, and international law is the product of governmental actors striving for coordination of their mutual interests. International law, in other words, is the apotheosis of the social contract: it is predicated on the analogy between the sovereign state and the unified self. Purvis points out that liberalism in international law, as elsewhere, can be understood as a philosophy that combines an atomistic psychological assumption with a radical epistemology about morality. The liberal psychological understanding is sovereign-centered, with world order representing nothing more than a social contract among sovereigns. The epistemological assumption is the principle of subjective value, leading to the claim that decisions about morality can only be made by the international order's atomic components, its sovereigns. ${ }^{32}$ There is no need to explain at length the lack of sacrifice and the erotic in international law. We can, again and again, study the unerotic consequences of liberalism and universality by looking to nation-states' unwillingness to invest bodies, money, or meaning into NATO or UN projects.

Europe as Style, Expertise, and Project

It stands to reason that Europe's cultural artifacts and symbols, too, received their share of such enlightened liberal ethos. The world of Brussels' office towers was designed to embody the technical coolness and the

30 Saturday Evening Review, quoted in DereK Heater, The Idea of European Unity, New York: St. Martin's Press 1992, at 148.

${ }^{31}$ See Monnet's text, published in the first issue of the Journal of Common Market Studies: Jean Monnet, A Ferment of Change, Journal of COMMON MARKET STUdies 1 (1962), at 203, reprinted in NELSON/STUBB (EDS.), THE EUROPEAN UNION (supra note 28), at 19 et seq.

${ }^{32}$ Nigel Purvis, Critical Legal Studies in Public International Law, 32 HARV. INT’L L.J. 81 (1991), at 93-4. 
modernization of the old continent. It was a world of xeroxed working documents and greyish-greenish office furniture, of simultaneous translators in soundproof cabins featuring multi-channel cables, of license plates in blue-white-red and recently founded European schools which taught more than three foreign languages and transnational history. This sat well with the then zeitgeist of sky-scrapers, autobahns and nuclear power plants: where such controlled technique was to rule, national idiosyncrasies and peculiarities became mere folklore and, thus, superfluous. Europe was in the hands of technocrats. ${ }^{33}$

The international element of the Union (e.g., the European Council and the Council of Ministers) is closely associated with contractarianism and liberalism. Both are political theories which are speechless in the face of sacrifice. A similar charge may be levelled at the Commission whose mode of governance is hostile to the idea of sacrifice, too. The Commission pools expert knowledge and seems like governance through management and technocracy epitomized. There is a diffusion of accountability through the rise of comitology. Expert management, however, may produce an efficient and perhaps even satisfactory distribution of society's resources, but it cannot produce the historical-communal understanding of self-identity that characterizes the rule of law as an experience of political order. To the expert, it doesn't matter how the present state of affairs came about. Loyalty may appear irrational. Management, as a form of science, knows no borders. One may say that the truth of law lies always beyond the law itself. Law is silenced by claims of expert knowledge that purport to provide their own grounds of authority. Scientific expertise always speaks for itself. It relies on no authority apart from itself, whereas law, on the other side, never speaks in its own voice. Like every scientific voice, management exists in the present. It tests the past and future against present interests. Law tests the present against the past, while action tests the present against the future. Management is in history but is not itself historical. ${ }^{34}$

Another facet of Europe as a project of modernity becomes visible in the oft-used metaphor of Europe as a project. This is one of the central motifs of modernity. "In modernity, Man's finitude becomes reconciled with the infinite and eternal, in terms of progression... [as] an interim apotheosis, one which rejects the preceding being but which also contains that being and prefigures all the object is yet to become. ${ }^{635}$ European academic literature will not tire in emphasizing the project nature of integration, and the procedural nature of Union law. The Treaty of Rome, is what we read, did not lay down a static legal order which was complete from the beginning.

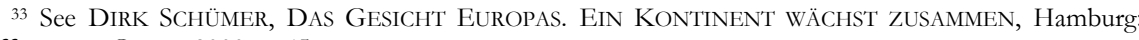
Hoffmann \& Campe 2000, at 45.

${ }^{34}$ KAHN, REIGN OF LAW (supra note 19), at 182.

35 Peter Fitzpatrick, The Mythology of Modern Law, London/New York: Routledge 1992, at 40 .
} 
Rather, European integration is said to be a legislative process characterizing the Union as a legal system evolving over time. The Court, too, cashes in on the myth of progression by privileging the teleological method of interpretation. ${ }^{36}$ Progression, it seems, becomes an essential element in the mythical structure of the Community legal order. The Union cannot compete with the law of nation-states as a source of order or transcendent being in terms of what it is. It can only attempt to do so in terms of what it is not, and in terms of what it well be. ${ }^{37}$

There is hardly anything new in noting that the Union is of little use as a projection surface for emotional identification. Jacques Delors, as President of the European Commission, remarked that "you don't fall in love with an internal market without borders". Basically, the whole debate about democracy and legitimacy is about little else. This is particularly true since Community competencies have extended into fields that used to be exclusive domains of the nation-state. Political science has described the outcome as a situation of "dual sovereignty" 38 and demanded that a European identity legitimize the exercise of European governance. However, there is little merit in such statements. The real question is what makes integration possible, and here we are faced with a dazzling variety of possible solutions. The proposals include everything from shared values and ends (such as welfare statism) $)^{39}$ to the recognition of difference as unifying paradigm. ${ }^{40}$ It is true, debates about the conditions of integration are in abundance, the reason being the development of modernity under the sign of postmodernity. The Union, however, witnesses a debate that is fiercer than others, possibly because the foundations of its legitimacy are in question. The reason is precisely this: The Union legal order, as a rational legal order, is unable to use the same resources as the nation-state. I believe that this is a theme to be found in all of integration theory literature, be it political science, law, sociology, or cultural theory. My own view is that it is possible to understand almost all flash-in-the-pans - nation and nationalism, state and statism, Volk and ethnos, identity and constitution - through this lens.

36 Thomas Oppermann, Europarecht, 2nd ed., München: C.H. Beck 1999, Rec. 685.

${ }^{37}$ James Henry Bergeron, An Ever Whiter Myth: The Colonisation of Modernity in European Community Law, in: Peter Fitzpatrick/James Henry Bergeron (eds.), Europe’s Other: European Law between MODERNITY AND POSTMODERNITY, Aldershot u.a.: Ashgate Dartmouth 1998, 3, at 14.

${ }^{38}$ M. Rainer Lepsius, Zwischen Nationalstaatlichkeit und westeuropä̈scher Integration, in: BEATE KOHLER-KOCH (ED.), STAAT Und DEMOKRATIE IN EuROPA, Opladen: Leske + Budrich 1992, 180, at 185.

${ }^{39}$ WeILER (supra note 5), at 246; Frank R. Pfetsch, Die Problematik der europäischen Identität, Aus POLITIK UND ZEITGESCHICHTE B 25-26/98, 3; Jacques Le Goff, Ein uniforms Europa wäre langweilig (Gespräch mit A. Reif), UNIVERSITAS 1998, 290.

40 Zygmunt Bauman, Moderne und Ambivalenz. Das ENDE Der EINDEUTIGKEIT, Frankfurt a.M.: Fischer TB 1995; Helmut Dubiel, Unversöbnlichkeit und Demokratie, in: WiLHELM HEITMEYER (ED.), WAS HÄLT DIE GESELLSCHAFT ZUSAMMEN?, Frankfurt a.M.: Suhrkamp 1997, 425; HANS-MARTIN SCHÖNHERR-MANN, Postmoderne Theorien des Politischen. Pragmatismus, Kommunitarismus, Pluralismus, München: Fink 1996, 101 et seq. 


\section{Europe as Imagined Community}

The Union, of course, has not turned a blind eye on this dilemma. The Commission, above all, has commissioned countless studies, initiated working groups, and written up White Papers in order to test social acceptance of the Union, to define problem areas, and to work out solutions. In addition, the Commission, long before 1993, embarked upon various initiatives in the fields of media and information policy to promote integration in the sphere of culture by enhancing what it saw as "the European identity". These initiatives are not without a certain comic effect I will return to this in a moment -, which is why scholars tend to underestimate the Commission's prowess. The Union's demiurges know their political theory. They have read Hobsbawm and have learned that history is central to the imagining of community, for how people experience the past is intrinsic to their perception of the present. History, they know, is also fundamental to their conception of themselves as subjects and members of a collectivity. Following Hobsbawm and Ranger ${ }^{41}$, they have focused on the "invention of European traditions" and on practices which seek to inculcate certain values and norms of behavior by implying continuity with the past. The past, like social memory, is a construction, actively invented and reinvented. The Commission might also have learned from Benedict Anderson's highly influential "Imagined Communities". Anderson defines nations as "imagined political communities" because its members will never know, meet or even hear of most of their fellow-members, yet in the minds of each lives the image of their communion. His theoretical point of departure is, indeed, mass-sacrifice for the nation and, ultimately, death. Death brings the threat of oblivion. In a secular age we increasingly look to posterity to keep our memory alive, and the collective memory and solidarity of the nation helps us to overcome the threat of oblivion. Nations are characterized by symbols of commemoration, notably the Tombs of Unknown Soldiers, which suggests that nationalism, like religion, takes death and suffering seriously (in a way that Marxism and liberalism do not). It does so by "transforming fatality into continuity", by linking the dead to the yet unborn. The nation, according to Anderson, is particularly suited to this "secular transformation of fatality into continuity, contingency into meaning", since nations "always loom out of an immemorial past, and, still more important, glide into a limitless future. It is the magic of nationalism to turn chance into destiny." ${ }^{42}$ This is just what the Commission had in mind: transforming contingency into meaning. However - unfortunately, if you want -, the Commission had no fatalities at its disposal it could turn into continuity. Perhaps, here is the reason why its initiatives all too often appear both helpless and comical.

41 Eric Hobsbawm \& Terrence Ranger, Introduction: Inventing Traditions, in: ERIC HOBSBAwM \& Terrence Ranger (EDS.), The InVEntion OF Tradition, Cambridge: Cambridge UP 1983.

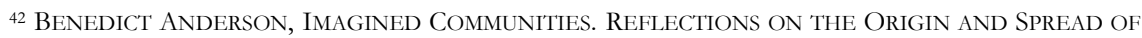
NATiONALiSM, London/New York: Verso, rev. ed. 1991, at 11-2. 
For the Commission, the first significant step towards defining a cultural basis for European unification came in 1973 with the signing of the "Declaration on the European Identity". The then nine Member States declared, inter alia, that they shared "the same attitudes to life, based on a determination to build a society which measures up to the needs of the individual"; that they each wished to ensure that the "cherished values of their legal, political and moral order are respected"; and that they were determined to defend "respect for human rights", "the principles of representative democracy, the rule of law" and "social justice" (the "ultimate goal of economic progress"). The 1974 summit recommended measures for protecting rights of Europeans and a specific policy for forging a "People's Europe" through "concrete manifestations of the European solidarity in everyday life". The Commission got a green light to pursue cultural initiatives "in order to affirm the awareness of a common cultural heritage as an element in the European identity". The emphasis of consciousness-raising as a strategy for bringing Europe "closer to its citizens" and creating "Europeans" thus signalled, writes Shore ${ }^{43}$, a new departure in EU approaches to the neglected domain of culture. This departure received another boost by the disappointingly low turnout in the 1984 European Parliament elections. The European Council agreed to establish an ad hoc Committee for a People's Europe whose task was to suggest measures to "strengthen and promote the Community's identity and its image both for its citizens and for the rest of the world. The Committee was headed by Pietro Adonnino and produced a number of reports the following year. These reports stressed that it is "through actions in the areas of culture and communication, which are essential to European identity and the Community's image in the minds of people, that support for the advancement of Europe can and must be sought". They identified several areas to possess popular appeal as sites for promoting the "European idea". These included a Europe-wide audio-visual area with a truly European multilingual TV channel ("in order to bring the peoples of Europe closer together"), a European Academy of Science ("to highlight the achievements of European science and the originality of European civilization in all its wealth and diversity"), and a Euro-lottery with its prize-money awarded in ECU ("to make Europe come alive for the Europeans"). The reports called for the formation of European sports teams, the inauguration of school exchange programs and voluntary work camps for young people, and the introduction of a stronger European dimension in education. All of these measures were designed to enhance European consciousness and Europeanize the cultural sector.

This approach to Europe is still very much in fashion, as the White Paper on "European Governance" and the attendant Working Group reports demonstrate. Working Group 1a dealt with "Broadening and Enriching the

${ }^{43}$ Cris SHOre, Building Europe, London/New York: Routledge 2000, at 45. 
Public Debate on European Matters". It found its purpose "in the sobering and well-documented reality that, despite all of the efforts made by Europe's institutions over the last decade, very few convincing answers have yet been found to the cry: "how can we take Europe closer to its citizens?". ${ }^{44}$ While the Union's competences and responsibilities very closely resemble those of most nation-states, its institutions do not have a relationship with the general public "that remotely compares with that of national institutions". ${ }^{45}$ Public support, therefore, is far from overwhelming. Knowledge of European affairs is low; prevailing attitudes to the Union are characterized by either indifference or lack of knowledge or a combination of both. ${ }^{46}$ The Working Group maps the way forward by pointing out that decision-makers need the support of an informed European public and the creation of a "collective intelligence" on European issues. Then you'll find the heading "Enlightenment could lead to more popular support". ${ }^{47}$ In practical terms, the Group suggests partnership networks of journalists, teachers, professors, associations, etc., to foster dialogue "close to the ground" and "establish links between EU institutions and civil society". One of the most important proposals is that "The EU must be Taught". 48

\section{Europe's Iconography}

Most importantly, the Union has recognized the overwhelming importance of symbols. Being not a "natural" but an "imagined" community, it needs to be constructed through complicated ideological, political and cultural mechanisms and procedures. Such construction and re-construction takes place discursively. The re-construction of community as European Union touches upon the self-understanding and the practices of its members, their bodies, and their construction of the "Other". Discursive constructions build on communication in order to develop, and generalize, an image of oneself. They make use, not only of narratives, but of images, media, and cultural artifacts of all kinds. "Imagined communities" have to do with "imago", too. Objects become images of meaning. ${ }^{49}$

It is here that EU iconography comes to the fore. The Adonnino Committee recommended various "symbolic measures" for enhancing the Community's profile. Foremost among these was the creation of a new EC emblem and flag. That flag was taken from the logo of the Council of Europe. It boasts twelve golden stars which form a circle against a blue

\footnotetext{
${ }^{44}$ Report of Working Group 1a, at 8.

${ }^{45}$ Id., at 9.

${ }^{46}$ Id., at 11.

${ }^{47}$ Id., at 14.

${ }^{48}$ Id., at 16.

${ }^{49}$ See the excellent collection of essays in UlRiCH BIELEFELD/GISELA ENGEL (HrSG.), BILDER DER Nation. Kulturelle und politische Konstruktionen Des Nationalen Am BeginN Der EUROPÄISCHEN MODERNE, Hamburg: Hamburger Edition 1998.
} 
background, and professes to be a symbol of everything that is said to make Europeans European: from the Occidental via the Religious to the Esoteric. The number of starts is fixed, twelve being (as the Council of Europe has it) a symbol of perfection and plenitude, associated equally with the apostles, the sons of Jacob, the tables of the Roman legislator, the labors of Hercules, the hours of the day, the months of the year, or the signs of the Zodiac. Twelve is also a representation of the Virgin Mary's halo of stars in the Revelation (from which, according to some interpretation, the new Messiah will be born). Thus, it seemed the symbol par excellence of European identity and European unification, a rallying point for all citizens of the EU.

There are countless other symbolic vehicles for communicating the "European idea". Take, above all, the European anthem, which is the overplayed "Ode to Joy" from Beethoven's Ninth Symphony, and which is available as high-quality recording or, perhaps for the busy, compressed recording on the Union's web site. ${ }^{50}$ Take the thousands of Jean Monnet Awards, the European Woman of the Year Awards, the variety of European Year of the Whathaveyou (Conema, Culture, the Environment), or the officially designated Europe Day (it's May $9^{\text {th }}$, commemorating the Schuman Declaration in 1950). Take the European Literature Prizes, the standardized European passport, the European license plates, the stamps bearing portraits of EC pioneers, or the European city of culture initiatives. The political aims behind these initiatives were, of course, ambitious, trying nothing less than to reconfigure the symbolic ordering of time, space, information, education, and the media, to reflect the "European dimension". In the end, it seems, all these initiatives failed miserably. ${ }^{51}$ What's more, they are not without a certain comic effect. It was Kierkegaard who said, "Just as much pathos, just as much comic effect. They secure each other." At this point, we are in the midst of a discussion of aesthetics. What, after all, is pathos? Pathos suggests stylishly domesticated passion. That is mistaken though. The new and distinctly European problem of pathos is not life's eventful turbulence, but rather the paralysis of all expression in a hieratic world of gestures. Formulas of pathos are designed to formally inject new tension into a frozen, rigid world and make it move again. ${ }^{52}$ Pathos is thus a final escape from problems of meaning - and that is the context to discuss the European pathos not just of anthems and flags, but of the ConstitutionTo-Be and the Charter of Fundamental Rights as well.

To speak of pathos is to speak of the aesthetic. It is impossible, through purely functional description and analysis, to capture the gestalt of the Union. Description and analysis today will have to move to, or at least include, the level of the aesthetic. The much despised and oft-scolded world of consumerism has taken this to heart long ago. Legal analysis has not. The

\footnotetext{
${ }^{50}$ http://europa.eu.int/abc/symbols/anthem/index_en.htm.

${ }^{51}$ A recent OPTEM study confirms this finding (supra note 16).

52 See Norbert BolZ, Die KONFORMisTEn DES ANDERSSEINS. München: Fink 1999, at 119-20.
} 
student of the European Union and its law will, at first glance, discover a huge variety of approaches and schools. On closer inspection, though, she will discover a core of sameness. The EU narratives are tried and true and reminiscent of a round of old buddies, having conversations, either affirmative or critical, which unfailingly sport a core of what you might want to call consensus, or at least, affinity. Nevertheless, equally unfailingly, they seem to miss the nerve of the Union and its problems.

Recent studies of consumerism show what I mean. Daniel Harris, for one, attempts to recover the suppressed aesthetic data of our lives and to make the vast archive of subliminal images accessible to conscious analysis. He feels it necessary to describe consumerism on the level on which the consumer actually experiences it: on the visceral level of the senses, the bodies, "from the point of view of the hand reaching for the soup can on the store shelf, the ears listening to the boom box broadcasting the sounds of a cool, refreshing soft drink splashing into a frosted glass, and the eyes fixed on the screen of the multiplex as the Titanic sinks". ${ }^{53}$

The Union, too, must be subject of aesthetic discourse. It is a bit surprising that it practically isn't because for decades now, the Commission has been talking about "A Citizens' Europe". The citizen perspective should be important then, and it would be enormously helpful to examine the Union on the visceral level on which the Union citizen actually experiences it. Much less surprising than the lack of aesthetic discourse would be the analytical result, which is nothing less than disastrous. The Commission continually bemoans the fact that Europeans feel alienated from the Union, that they have disappointed expectations, that there is a widening gulf between the Union and the people it serves - and wonders why. ${ }^{4}{ }^{\text {The }}$ answer is right there, in its face, on its own web site. Look up the things I have pointed out above (flag, anthem, prizes), and you will have an intuitive understanding of the citizens' complete indifference towards "their" Union.

\section{A Cultural-Legal Study of the Union's Problem}

The European Union's problem of meaning is, of course, the problem that its citizens are completely indifferent towards it. The Union produces texts which nobody reads and nobody knows. Nobody is interested. That has fatal consequences. Texts, legal texts above all, are a polity's memory, if you want the hard disk storing authentic witness. As I have shown (II.), in nation-states, some legal texts - constitutions - embody ideal historical meaning which links the present to the past, to some point of origin, like a revolution and the consecutive writing of the constitution. Such texts constitute states as "imagined communities" and continue them over time.

${ }^{53}$ Daniel Harris, Cute, Quaint, Hungry and Romantic. The Aesthetics of Consumerism. New York: Basic Books 2000, at xiv.

${ }^{54}$ For a recent example of the Commission's stunned disbelief and disappointment see Commission, European Governance - A White Paper, COM(2001) 428 final, Official Journal of the European Communities $2001 / \mathrm{C} 287 / 01$, at 5. 
They can claim loyalty as their source of moral support because they are "ours".

Union texts are not "ours". They are just texts, empty shells with no roots. Rather than an embodied set of meanings they are seen as a set of ideas without the power to make a claim upon the citizen. They do not bear deep social meaning. There is no myth of origin; there are no bodies willing to be invested into ideas, no traces, no sacrifices. There is nothing that could convey authenticity on EU texts. Ultimate meaning disappears behind the semantics of rationality. Because of the lack of sacrificial meaning, Europe, in contrast to all its rhetoric, is not a new beginning really, since what is missing is the founding, creative power. The political future will look like the political past: belief in novelty, which is behind sacrifice, is non-existent. In the Union, then, there is nothing to remember, and hence nothing to maintain. Union texts do not constitute a collective self; rather, they constitute a Common Market. Markets cannot tell us who we are: they operate through desires, which are mere placeholders. We have no character, only desires. The desiring body is not read, it is satisfied. It makes no public appearance to others and leaves no trace. Its very existence is a matter of indifference to others. ${ }^{55}$ Money, the universal means of exchange on the market, is the perfect example. There is nothing with less memory than money. There's an old saying that says you shouldn't conduct money business with friends or foes. The perfect business partner is thus someone completely indifferent, gauged neither for nor against us. ${ }^{56}$ The category of price, it seems, makes history and individuality disappear. Remarkably, it is precisely at the point of this total indifference where the European rationality of the market and the European social contract - concluded by unencumbered selves behind the veil of ignorance - converge.

No history, no identity, no individuality - that's not how you produce and maintain social and political meaning. We do not reach ourselves through markets and reason alone. We cannot reason about, or trade in, the symbolic dimension of meaning. Whereas money and reason create borderless fluidity, political and social meaning needs to be rooted. The Union's legal texts are lacking in the way they look to the past, and they are unable to stabilize anything deeper than the ever-changing fluid surface of trade, travel, and consumption. That is the reason why the EU, in the eye of the beholder, appears so breathless. As there is no memory to store meaning, meaning needs to be generated through political action, again and again and again. Meaning, in the Union, exists only within transitory and forgetful moments. It is a-historical and respects neither borders nor authenticity. Without reservoirs of meaning, there can be no room or time to have a breather, read the legal texts and realize their ideal content. There can be no stable meaning; there can be only frantic, restless and ceaseless production of ever-

\footnotetext{
${ }^{55}$ KAHN, REIGN OF LAw (supra note 19), at 86. See also supra, II., “The Role of Sacrifice”.

${ }^{56}$ GeOrg Simmel, Philosophie Des Geldes (1900), Frankfurt a.M.: Suhrkamp 1989, at 290-1.
} 
new meaning. Europe, in this sense, is truly revolutionary, because political action may never come to an end. In the conflict between loyalty and responsibility, the latter prevails. Responsibility, however, is the mode not of law, but of political action. Citizens, therefore, see Europe as politicians negotiating and re-negotiating. Politicians speak the discourse of responsibility; the future is a horizon of possibilities. Europe is the neverending project. History is being rewritten and re-rewritten. It is in the nature of revolutions to break with the past - and here is the reason why all references to occidental culture, Christendom and Latin (or French) as the once lingua franca seem so unpersuasive. Revelation, which shares a temporal structure with revolution, constructs meaning not from history, but from truth which manifests itself in and through action. That is why we are hardly able to read through the Treaty of Nice before, with its ink not dried yet, we hear talk of the post-Nice process and plans for the next Intergovernmental Conference.

\section{Europe and Consumer Aesthetics}

The Union, in its attempt to be close to its citizens not only recognizes this deficit, but has initiated counter-measures. These counter-measures can best be understood, I believe, from the perspective of consumer aesthetics. There is no substance in them, they are an effort in aesthetics. What lies behind them is a principle of consumerism.

One of the most important functions of the aesthetics of consumerism, writes Harris, is to provide us with an emotional cushion, a form of camouflage, a credible disguise for a culture that refuses to admit the truth about itself. We don't like to see ourselves as consumers, or our culture as that of consumerism. We continue to pretend that our values are those of an intimate world full of Mom-and-Pop businesses, rather than an overpopulated megalopolis dominated by multinational cartels. The aesthetics of consumerism helps us keep that faith by hiding consumerism from consumers. They combat our estrangement from a world packaged in plastic by restoring the "aura" of the handmade to our commodities. They also shore up our sense of selfhood and individuality, which have been deeply compromised by the conditions of urban society. The aesthetics of consumerism have incorporated our distrust into their marketing techniques. They have built into consumerism symbolic forms of resistance to it: ineffectual strategies of rebellion that make consumers believe they are loners or oddballs, immune to advertising strategies rather than at the mercy of Madison Avenue. ${ }^{57}$ The perfect disguise for conformity has become rebelliousness. You buy shoes, for example, which remind you of running shoes, and feel like a rebel battling the conformist obligation to wear conservative shoes with dark laces to work. You're being in control, capable of action and rebellion, rather than being controlled: you "dare to "be

\footnotetext{
${ }^{57}$ HARris (supra note 53), at xxi-xxiii.
} 
different"'. In fact, all you actually do is wear fashionable shoes, just like everybody else.

It is possible to identify a number of broad principles that govern the appearance of popular culture, among them cuteness, zaniness, coolness, and idyllic quaintness. Quaintness responds to the discontent of a culture trapped in an eternal present. It disfigures things to eradicate the stigma of their newness, their disturbingly characterless perfection which smacks of the alienating anonymity of assembly lines. Quaintness also compensates for the absence of real personal history. We hide our sense of uprootedness by creating a sepia-tinted simulacrum of history and "instant" traditions. Even, and especially, those who are cut off from history, like we often are, feel the need to establish something like continuity with the past. The result is quaintness riding roughshod over authenticity. It often mourns the loss of cohesion in family life and of the intimate circle brought together around the fireplace by darkness and cold weather. Quaintness is the industry's tool to help reduce our deep-seated distrust of advertising and our fear of shoddy goods. It rectifies problems that consumerism itself creates, and allows us to express our discontent with consumer culture and society.

Quaintness is also what the Union is after. As a vehicle, it has chosen a number of romantic idyllic items; one of them is the Constitution-To-Be; another is the Charter of Fundamental Rights.

\section{The Charter of Fundamental Rights as Consumer Aesthetics}

The EU Charter of Fundamental Rights, solemnly proclaimed during the IGC in Nice on December 7, 2000, ${ }^{58}$ serves the same purposes as quaintness in consumer aesthetics. Both, the appearance of popular culture in the form of quaintness and the Charter, are meant to offer us symbolic ways of expressing discontent, and to neutralize our feelings of inferiority, caused by our status as objects, not subjects, of globalization and international trade.

The Charter has no other use than that associated with consumer aesthetics. In the face of the laughter and merriment surrounding the Charter it is important to point out that the European Court of Justice has developed, for more than three decades now, a rich and differentiated human rights case law. Since 1969, at least, the Court has been ready to invalidate Community legislation that violates EC fundamental rights. Does the newly proclaimed Charter offer better protection of fundamental rights? The Charter itself says no. In its Chapter VII, it admits that neither the scope of the rights it guarantees is broader, nor the level of protection is higher, than the case law status quo.

Clarity is another common justification for the Charter. However, like all human rights documents, the Charter is drafted in magisterial, sometimes

\footnotetext{
58 Official Journal of the European Communities, December 18, 2000, C 364/01 (http://europa.eu.int/comm/justice_home/unit/charte/pdf/texte_en.pdf).
} 
cloudy language. While there is much to say in favor of such constitutional traditions, clarity is not one of its features. ${ }^{59}$

Is it, then, at least a symbol of shared European identity? Hardly. While it was solemnly proclaimed, it has no binding legal force. Some regard this as a symbol, not of shared identity, but of European impotence and of refusal to take rights seriously. ${ }^{60}$ Even if it is bound to become law some day, doubts remain about its integrative force. Europe already has a pronounced culture of rights, with a tightly knit web of fundamental rights protecting its citizens: bills of rights in Länder and federal constitutions, the EJC rights jurisprudence, the ECHR and its human rights court in Strasbourg, and the two 1969 UN Covenants on Civil and Political Rights, and on Economic, Social, and Cultural Rights. Waving yet another catalogue of rights in a culture of rights saturation will not make the citizen any closer to the Union. ${ }^{61}$ It is an additional delightful detail that the community of Europeans is expected to assemble under the umbrella of a Charter that will grant them legal protection against legislative acts from Brussels - a European community against the European Community.

Why, then, is it that so much money, and so many resources, are lavished on the Charter if there is so little to say for it, either legally or symbolically? The answer is, it's aesthetic. The Union wants the Charter to de-stigmatize itself and to neutralize our distrust. The vehicle is quaintness. The Charter compensates for the lack of real European history. Notwithstanding all rhetoric the Union is a young entity with no model or predecessor. Europe has, not one story, but a multitude of stories which are contradictory, competing, and violent, and which need to be reconciled with each other. Europeans think of "their" Union as faceless Brussels bureaucrats, smooth, modern, insipid, and completely characterless. The Union suffers from its unrooted newness. Its insatiable surge forward cuts it off from the past. That provokes its citizens' distrust, and they refuse it their loyalty. The Union is seen as the epitome of bureaucratization and centralization. It rationalizes life (through international division of labor) and depersonalizes the market (through internationalization). It emphasizes competition and transborder trade of goods through the Common Market, thus appearing as commodification of values personified. In addition, there is the peculiarly modern angst because truths and certainties crumble, identities become fragmented and transitory, feelings of displacement and uprootedness grow, and all that is solid melts into air. The Union ideally attends to such anxieties. $^{62}$ 96.

${ }^{59}$ J.H.H. Weiler, Editorial: Does the European Union Truly Need a Charter of Rights?, 6 EuR. L. J. 95 (2000), at

${ }^{60}$ Weiler (supra note 59), at 96.

${ }^{61} \mathrm{I}$ am by no means alone with this judgment. See only WEILER (supra note 5), at 334-5.

62 WEILER (supra note 5), at 260-1. 
The Charter of Fundamental Rights is the Union's designers' program to steer in the opposite direction. The Charter's solemn declaration evokes the spirit of the Virginia Bill of Rights of 1776 and of the Déclaration des droits de l'homme et du citoyen of 1789. In part, this is deliberately done in order to create the impression that the Union's roots reach back to the origins of modern democracies. Perhaps, what is hoped for is not merely a solution to the problem of lacking history and character, but to that of democratic legitimacy as well. By proclaiming a catalogue of rights, the Union adorns itself with the embellishments of the fountains of democracy - among them, the principle of popular sovereignty. ${ }^{63}$

At the same time, in reaching back to 1776 and 1789, the Union creates patina for itself. Patina is a physical property of material culture which consists in the small signs of age that accumulate on the surface of objects. The surface of objects, originally in pristine condition, takes on a surface of its own, being dented, chipped, oxidized, and worn away. This physical property is treated as symbolic property: it encodes a status message and is exploited to social purpose. That purpose is the legitimation, authentication, and verification of status claims. ${ }^{64}$ Just as newly acquired wealth, in a world of traditional hierarchy, was under pressure to provide visual evidence of the authenticity of its status claim, the Union is trying to secure and verify its status in a world of nation-states. The Union is the nouveau riche in Europe and needs to prove its wealth is not fraudulent. The gatekeeper that controls status mobility is patina. The Charter, of course, is meant to be the chipping and oxidization on the EU's pristine surface.

The Charter also conjures up an atmosphere of solidarity, brotherly love, and transgenerational community (the political theory equivalent of the intimate circle gathering around a fireplace). The Preamble, for instance, provides that "[e]njoyment of these rights entails responsibilities and duties with regard to other persons, to the human community and to future generations." The Charter's individual chapters have the following headings: I - Dignity; II - Freedoms; III - Equality; IV - Solidarity; V - Citizens' Rights; VI - Justice. Here is a world resurrected before our eyes that has never known the critique of rights developed by legal realism, CLS, communitarianism, feminism, and postmodernism. The Charter appears as a means to develop a moral and ethical foundation for the Union. It draws on the twin sources of the Ideal and the Other. On the one hand, it refers us to the informing ideal of an ethos of collective societal responsibility for the welfare of the individual and of the community as a whole. On the other hand, the Charter refers to the Other, that which is excluded but nevertheless there, such as stories of injustice and fear, or the barbaric orient. However, both references are (aesthetically, at least) unconvincing. They remain

\footnotetext{
${ }^{63}$ This connection has also been detected by Craig (supra note 9).

${ }^{64}$ On the function of patina in material culture see GRANT MCCRACKEN, CULTURE AND CONSUMPTION, Bloomington/Indianapolis: Indiana UP 1988, at 31-43.
} 
wooden and simplistic in a saturated liberal society whose role model is the Lebensästhet (life aesthete). ${ }^{65}$ One accepts them the same way one accepts a shoe manufacturer's claim that its shoes aren't shoes but the result of a dream.

The creation of the Charter also speaks for my thesis that it is designed to create an atmosphere of quaintness. The European Council, meeting in Tampere in October 1999, decided to establish an ad hoc body, made up of 15 representatives of the heads of state and government, the President of the European Commission, 16 Members of the European parliament and 30 national Members of Parliament. On its first meeting, that body called itself "Convention" - a name that smacks of Philadelphia and Paris. The German version is even more telling than the English one. The body is called "Konvent" - a Konvent being "1. a) a community, esp. of nuns, bound by vows to a religious life under a superior; $b$ ) a gathering of protestant priests for further education; 2. a) a weekly gathering of the [active] members of a fraternity; b) collectivity of lecturers at a university; 3. (no pl., hist.) the convention during the French Revolution." Atmospherically, this is not insignificant. It fits well with the name of the web site that documented the drafting process of the Charter: http://db.consilium.eu.int. "Consilium" is Latin, the former European lingua franca, and conjures up the image of a Roman council of wise old men, white-bearded and clad in togas. That image is linked to progress and modernity surging forward. "Consilium" is amended by "eu.int" - a cipher of globalization ("int") à la Europe ("eu") -, and it appears in the internet, the most progressive medium of communication with virtually unlimited possibilities. Such connection of Old and New, of tradition and modernity, of local roots and global aspirations, also shows in the Convention's email address: fundamental.rights@consilium.eu.int. The old lingua franca appears in the same breath, the same address even, as the new lingua franca, the world language English.

Finally, the choice of the Convention's President fits well into the picture, too. Roman Herzog is a former professor of constitutional law and Justice and President of Germany's Federal Constitutional Court - thus standing for cool rationality, academic smartness, and legal expertise beyond doubt. He is also the former President of the Federal Republic of Germany standing for political vision and statesman-like stature. Most importantly though, he was born in a small town in Bavaria (Landshut), was married, and has two sons. Despite his steep career, Herzog conveys the impression of somehow being native and rooted in the soil, sometimes even of that specifically Bavarian snugness.

All these phenomena serve an aesthetic purpose. That purpose is to soothe our deep-seated distrust of the smooth European machinery and its

65 Johannes Goebel \& Christoph Clermont, Die Tugend Der Orientierungslosigkeit, Berlin: Volk und Welt, $3^{\text {rd }}$ ed. 1998. 
faceless bureaucracy. A "Convention" is neither a machinery nor a bureaucracy. Its members have a distinctive personal image. The listen to "us" (represented by pressure groups) and take into account our reservations and suggestions. Herr Herzog even talks like someone from Landshut: How can he not be one of us? The stroke of genius that shows in the idea of a Convention is that in spite of all the idyllic coziness, the Union's twin attributes - rationality and expertise - are not weakened. On the contrary, they grow stronger because the drafting of the Charter rests with a body of experts which bears the name of a gathering of university lecturers, of a community of monks or nuns, or of a political body during the French Revolution - in Latin still. It must seem to the Union's architects that such a body will be able to scatter peoples' doubts without giving up the tried and true Union standard of administrative expertise. Under such conditions, anything becomes possible - even to talk Latin and Bavarian at the same time. Things that seemed incompatible become compatible. There is nothing that cannot be achieved. Is it any wonder that the Convention method is brought up every single time a new text must be drafted and another Intergovernmental Conference needs to be prepared? It must seem like the golden bullet that is able to blast a hole in the Gordian knot which blocks communication between the Union and the citizens that it wants to be close to.

\section{The Problem With Consumer Aesthetics}

There is much logical consistency in the Union's deliberate use of the aesthetics of consumerism. Today's citizens have turned, to a large degree, into consumers. Our personal salvation experiences are often founded upon consumption. "It is the consumer attitude which makes my life into my individual affair; and it is the consumer activity which makes me into the individual," writes Zygmunt Bauman ${ }^{66}$, and John Urry maintains that "citizenship is more a matter of consumption than of political rights and duties. ${ }^{\circ 67}$ Saatchi \& Saatchi Europe is a reality, and not a bad one at that. ${ }^{68}$ There is no reason, then, why Europe should not print the Charter's text on the wrapping of its product "European Union" in order to sell it.

The problem is that the Union actually believes that the Charter really is a step towards shared European identity. ${ }^{69}$ That is as if a shoe manufacturer actually believed its shoes weren't shoes but the result of a dream. It simply is wrong to suppose that under the Charter's influence, the people living in Europe will turn into European subjects, coming together in solidarity as a

${ }^{66}$ Zygmunt Bauman, Soil, Blood and Identity, 40 SociologiCAL REVIEW 1992, at 205.

${ }^{67}$ JOHn Urry, CONSUming PlaCes, London/New York: Routledge, 1995, at 165.

${ }^{68}$ See text supra with notes 20 and 21.

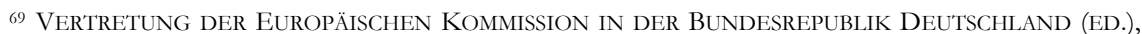
EuropÄISCHE GESPRÄCHE HEFT 2/1999: EINE EuROPÄISCHE CHARTA DER GRUNDRECHTE. BeitraG ZUR GEMEINSAMEN IDENTITÄT. EINE DOKUMENTATION. Berlin 1999. 
European Community. We have already seen where such belief leads: to the comical attempt to make use of nation-state artifacts. Indeed, those artifacts, in the nation-state, are able to transport political and social meaning. The Union's texts, like the Charter, however, are not. It is true that subjectivity, in the times of globalization, has come under increasing pressure. When locality gets devalued, and geographical space is cancelled out, people begin to feel like objects of transnational interests. Fundamental rights, however, the $\mathrm{n}^{\text {th }}$ catalogue at that, are no cure. The cure, as Bauman says, is playing the mobility game. Scope and speed of movement make all the difference between being in control and being controlled; between shaping the conditions of interaction and being shaped by them. ${ }^{70}$ It seems that to participate in the competition that races along before our eyes is to reconstitute subjectivity. Perhaps, the perils of the market are met effectively only by the weapons of the market. Besides that, fundamental rights pale into near-insignificance and seem like anachronistic window-dressing, at least if injected into the rationality of money and the market.

But let's be honest. In times in which society itself seems like a fancydress party, with identities designed, tried on, worn for the evening and then traded in for the next, we actually like anachronistic window-dressing. That's why we're delighted about the Charter. "If there is kitsch in our daily lives," writes Daniel Harris, the theorist of consumerism, "it is because there is kitsch in our minds." ${ }^{, 71}$

\section{The Promise of Europe}

A bleak future for Europe, it seems. But is it really? Europe's failure is not all-consuming. It is true, the Union's finality does not lie in a constitution that is able to make use, symbolically and aesthetically, of the deep structure of nation-state constitutions. That does not mean, however, that Europe is without options and promising finality. The future gestalt of the Union is very different from what is commonly assumed, though. While the Union cannot rely on imaginations of the political accessible to the nation-state, I believe it should consider confining itself to what is possible. That, of course, is the imagination of the political as consumption and market. In the remainder of this piece I shall argue that embracing liberal consumerism is Europe's unique option, which, in contrast to what cultural critics believe, does not mean Europe has to renounce all ambitious moral options.

\section{Post-traditional Society}

According to Luhmann, what is modern about modernity is the loss of authority. He defines authority as "the ability to represent the world in the

\footnotetext{
70 Zygmunt Bauman, In SEARCh OF Politics, Stanford: Stanford UP 1999, at 26.

${ }^{71}$ HARRIS (supra note 53), S. xx.
} 
world and to convince others of the same representation" ${ }^{72}$ Authority can be "founded on knowledge or power or on the knowledge of the future or on the ability to create it according to desire, in any case on the future." ${ }^{, 73}$ More than other forms of community, the European Union has a fixation on the future because of its imagination mode of political action and its underlying theme of responsibility. Loss of authority, therefore, hits the Union harder and faster. What seems to have taken the place of authority, says Luhmann, is something that may be termed a politics of understanding. Understandings "are negotiated positions that can be relied upon for a given time. They do not imply consensus, nor do they represent reasonable or even correct solutions to problems. They [merely] fix reference points that are removed from the argument for further controversies, in which coalitions and oppositions can form anew." 74

Such diagnosis resonates with similar observations on modern society. In particular, the relative confidence about the autonomy of the Subject has been shattered. While in the discourses of modernity the Self was constituted as an active agent resisting state violence and instituting a project of selfrealization in a process of liberation from constraining structures, we are now living in a "de-massified" network of social relations, with threats to the autonomy of the individual coming not from the "mass" which annihilates the autonomous individual but from the very self-expression of individuality itself. $^{75}$ The notion of universalizable selfhood which underlay the modern project has collapsed in a climate that celebrates difference, the Self as context-bound, and multiple identity projects. While modernity derived legitimacy from itself and not by reference to transcendental principles, the Self has now collapsed into a variety of projects, such as those of creed, race, and gender which do not accept any terms of universal reference.

Post-traditional society, then, is marked by pluralization. In place of a secure order of values and social positions there is a bewildering variety and fluidity of values, roles, authorities, symbolic resources and social encounters out of which an individual's social identity must be produced and maintained. This has been usefully summarized in four themes. ${ }^{76}$ Firstly, modernity is a post-traditional order in which fixed identities are neither ascribed nor unambiguously indicated. Identity, increasingly unanchored in tradition, religion etc., can only emerge from choice. Secondly, modernity involves a pluralization of lifeworlds in which each individual has to

\footnotetext{
72 Niklas Luhmann, Describing the Future, in: NiKLAS LuHMANn, OBSERVATIONS ON MODERNITY (translated by William Whobrey), Stanford: Stanford UP 1998, at 69.

${ }^{73}$ ID.

${ }^{74}$ ID.

75 Gerard Delanty, Social Theory in a Changing World. Conceptions of Modernity, Cambridge: Polity 1999, at 46.

${ }^{76}$ Anthony Giddens, MOdERnity AND SELF-IDENTITY. SELF AND SOCIETY IN THE LATE MODERN AGE, Cambridge: Polity 1991, at 84.
} 
negotiate multiple and contradictory identities as they traverse different public and private spheres. Thirdly, modernity replaces traditional authority with "methodological doubt" rather than the "certainty of reason". Truth is contextual, authority and expertise are provisional. Finally, modernity places mediated experience at the center of social life. Through commerce, the mobility of travel, the city and communications, ever more lifeworlds are made visible to us and become possible choices of identity. Through marketing and commercialization, this plurality of life is directly translated into consumer choices.

There is another theme, commercialization itself. ${ }^{77}$ Pluralization is intensified by subordinating culture to economic ends. On the one hand, consumption is regulated by purchasing power rather than socio-cultural rights and priviliges, thus allowing a great fluidity in the use of goods to construct identities and lifestyles. On the other hand, cultural values and meanings are ever-renewable resources for economic competition.

\section{Consumer Culture}

Consumer culture exemplifies the blurring and flattening of modernist distinctions. In the notion of postmodernist culture, commodities have been dematerialized and now exist purely as signs circulating within a political economy of signs. However seemingly infinite the number of different signs in circulation, they are all the same in being just signs. This, then, is the dedifferentiation of postmodern culture: the implosion of sign and reality (or, in semiotic terms, of sign and referent, connotation and denotation). The plane of signs and culture can no longer be anchored in "finalities" (Baudrillard) in the external world. Consumption, for example, is no longer anchored in the finality of need, nor knowledge in truth, technocracy in progress, history in a meta-narrative of causation and teleology. As a consequence, contemporary experience is depthless: there is nothing credible beneath or beyond the flat landscape of endless signification.

The critique, of course, is that of Jameson's "schizophrenic" subject of postmodernity ${ }^{78}$ Consumer culture, in this account, is a fancy-dress party in which we dress up our everyday lives in ever-changing costumes, driven by impulses which are themselves prompted by the life of the party rather than by the life outside it. The schizophrenic subject inhabits a purely present tense and is unable to form a coherent ego, and instead swims chaotically down a never-ending river of signification. The consumer confronts all of social life as a field of simultaneous and flat images from which to choose without reference to externalities or anchors.

That is a scary outlook. It leaves us, like in King Lear, bound to a chaotic world as to a "great wheel [that] runs down a hill". ${ }^{79}$ The torments are many,

\footnotetext{
77 Don Slater, Consumer Culture and Modernity, Cambridge: Polity 1997, at 84.

${ }^{78}$ Frederic Jameson, Postmodernism, Or the Cultural Logic of Late Capitalism, NEW LEFT REVIEW 1984, 146.

${ }^{79}$ See King Lear, 3.4.108-10.
} 
but they all boil down to the sickening feeling of perpetual uncertainty in everything regarding the future. The fast and continuously accelerating pace of change makes one thing certain, namely that the future will not be like the present. The quick succession of futures dissolving into a succession of presents also teaches that today's present - even its domesticated, tamed part - does not bind the future. There is little the individual can do to make sure that tomorrow's results will be achieved. If you will, we are fighting a losing battle. The above critique, then, rests in a desire of the impossible: On the one hand, we want to relish and practice our freedom while, on the other hand, we want a happy end guaranteed and the results insured. However, there is no risk-free freedom. Communitarianism, for one, has not come to terms with this simple fact. ${ }^{80}$

Europe's discourse includes, indeed, the prospect of consumer identity. That is hardly surprising, taking into account the Union's beginnings as an Economic Community. However, consumer identity meets with fierce criticism and is played out against "rich" conceptions of citizenship. Bashing consumer identity is the ever-reliable starting point for criticizing "market citizenship" and "bread-and-circus democracy". The common denominator is that "to define people as consumers and worker-producers is to undervalue their worth as individuals and the importance of the political process to good government. ${ }^{\prime 81}$ Underlying this critique is a powerful and enduring theme ${ }^{82}$ : to understand consumerism as a social pathology that can be played out against "culture". Most authors pursue this theme by trying to show that the hedonistic consumer culture is dysfunctional for the individual (it feeds off their modern insecurity) but functional for the system (it produces insatiable consumers). In this view, modernity dismantles a stable social order and reduces the social to the individual, and the transcendental to the calculated, rational, and material. The individual's sources of meaning become blurred under such conditions. Consumer culture, then, floods modernity with a torrent of values and meanings, both filling in the cultural deficits and constantly intensifying and exploiting them. There is an ineradicable nostalgia behind such a perspective: consumer culture can never replace the world we have lost, provide us with selves we can trust, or offer a culture in which we can be truly at home.

Consumption, however, is a meaningful activity. Humans do not consume like animals in that our relation to our needs and our environment is neither instinctive and programmed nor confined to the survival of the individual or the species. People understand their relation to things in the world in terms

80 Zygmunt Bauman, On Communitarianism and Human Freedom, or How to Square the Circle, in BAUMAN, POSTMODERNITY (supra note 22), 186; Ulrich Haltern, Kommunitarismus und Grundgesetz, KRITISCHE VIERTELJAHRESZEITSCHRIFT FÜR GESETZGEBUNG UND RECHTSWISSENSCHAFT 2000, 153.

${ }^{81}$ Dawn Oliver, What Is Happening to the Relationship Between the Individual and the State?, in J. JOWELL \& DAwn Oliver (EDS.), The Changing CONSTITUTION, Oxford: Oxford UP 1994, 461.

82 SLATER (supra note 77), 98-99. 
of projects and goals, social conventions and norms, concepts of what being human involves. ${ }^{83}$ Goods are meaningful, and their meanings are part of the making of social relations and social order. They are not arbitrary but deeply related to the underlying social divisions of a community. Take, for example, status symbols. Social stratification is directly mapped onto a division between kinds of goods and consumers. What's more, by using goods in accordance with their meanings we experience the social order as a compelling moral order and reliably reproduce it in everyday life. ${ }^{84}$

After all, the individual uses consumption to say something about himself, his family, and his loyalty. The kinds of statements he or she makes reflect only the kind of universe surrounding him or her. ${ }^{85}$ Normatively, there are theories that take seriously these new, "postmodern" configurations without resorting to shallow utilitarianism. ${ }^{86}$ The citizen at the center of a Europe thus conceived would resist such categories as virtue, republicanism, civic-mindedness, just as she resists classifications as Christian, commonality of values, shared history etc. Rather, citizens would assemble under a superficial neo-Durkheimian integrative umbrella of consumption rituals and codes. No doubt, this is more stressful than singing songs together around a campfire. But why pretend the world is, or can be remade into, a campfire community? Despite the overwhelming lament about the decline of culture and values, and the concomitant fragmentation of social life and decomposition of community, some strands of sociological literature emphasize the communal nature of consumption. According to this view, consumption takes on more and more social functions as a form of sociality. "Shopping is not just a functional activity," writes Rob Shields, and continues that "consumption has become a communal activity, even a form of solidarity." 87 The resulting groups are marked by their transient membership and their refusal of the "grand narratives" of hegemonic ideologies. They embrace the local authority of what is close to home, and thus are based on local territoriality. ${ }^{88}$ That would indeed make them affectual cliques which transgress the grid and group divisions of society, without neglecting the changeable nature of personal identity. ${ }^{89}$ The latest,

${ }^{83}$ ID., 131.

${ }^{84}$ ID., 148.

85 Mary Douglas \& Baron Isherwood, The World of GoOds: Towards an ANTHropology of CONSUMPTION (Harmondsworth: Penguin, 1979).

${ }^{86}$ Cf., for instance, Zygmunt Bauman, Postmodern Ethics, Oxford/Cambridge: Blackwell 1993.

${ }^{87}$ Rob Shields, The Individual, Consumption Cultures and the Fate of Community, in: LIFESTYLE SHOPPING. THE SuBjECT OF CONSUMPTION (Rob Shields ed.) (London/New York: Routledge, 1992), 99, 110.

${ }^{88} \mathrm{I} d ., 108$.

${ }^{89}$ It has been argued that the erosion of individual identities inevitably leads to the impossibility of community identity or the closure of insiders against outsiders: if the self is only an empty sign, then companionship as reciprocity is cancelled out by the radical isolation of these depthless souls. How can there be friendship as we know it, between anything but discrete individuals? See ARTHUR KROKER \& DAVID Cook, The Postmodern Scene. Excremental Culture and Hyper-Aesthetics (Toronto: New 
and perhaps best, example is former New York Mayor Rudolph Giuliani's response to the horrible terrorist attacks on Washington and New York. He asked New Yorkers to go back to enjoying their lives and go shopping. A serious German newspaper reported this under the heading: "Seid solidarisch, geht einkaufen". ${ }^{90}$

The schizophrenic consumer, from this perspective, is by far not the only possible consumer. The postmodern consumer is ironic and knowing, reflexive and aware of the game being played. She has considerable cultural capital and is able both to make sense of the wealth of mobile and detached signs and to treat them as just signs. We might imagine her obtaining pleasure not necessarily from the things themselves but from the experience of assembling and deconstructing images. ${ }^{91}$

\section{The Union and Its Citizen/Consumer}

There are far-reaching conclusions to be drawn in relation to the European Union. We have already seen that the image of what is a citizen needs to undergo revision. ${ }^{92}$ European citizenship cannot be defined through essentialist human rights, or exclusive demands on loyalty. It is very much the question whether or not it makes sense to craft social rights on to a laissez-faire economic framework that is indifferent, perhaps hostile to T.H. Marshall's concept of social citizenship - the more so at a time when the welfare state is being dismantled across Europe. There are signs that the two domains are increasingly being conflated, with "consumers" and "citizens" becoming essentially one and the same thing. The EU booklet "A Citizen's Europe" announces, for instance, "Every citizen a consumer.",93 Terrence Turner argues that the primary basis for political legitimation lies in a government's ability to guarantee "their citizens access to commodity consumption on a scale commensurate with their social aspirations. Consumption of commodities has thus supplanted the exercise of the traditional political functions of citizenship as the main mode of the construction - and thus control - of personal identity." 94 This is particularly true of the Euro-polity. Thus, Shore is right in suspecting that "the citizenhero of the new Europe appears to be the Euro-consumer." 95

\footnotetext{
World Perspectives and Macmillan, 1988). The concept of consumption transcending commodity exchange opposes this vision, insisting on the 'tactility' of 'contact communities' in the consumption process, as opposed to the 'contract communities' envisioned, for example, by Tönnies.

${ }^{90}$ „Show solidarity, go shopping“. Frankfurter Allgemeine Zeitung, September 24, 2001, No. 222, p. 47.

${ }^{91}$ SLATER (supra note 77), 197.

${ }^{92}$ See text supra with notes 66 and 67.

93 Pascal Fontaine, A Citizen's Europe, Luxembourg: OOPEC 1991.

${ }_{94}$ Terrence Turner, Reply to Stolcke, CurRent AnTHropology 36 (1995), $16,18$.

${ }^{95}$ SHORE (supra note 43 ), at 84.
} 
The Euro-consumer can easily do without constitutional pathos. What she needs is the possibility of free movement of goods, persons, and capital, freedom of establishment and to provide services, and a good measure of consumer protection. Europe's identity is not on the same level as narratives of sacrifices, ideal meaning written into bodies and texts, or constitutional interpretation as memory. That is the world of the nation-state. The Union has no such myth. Those who aim at constructing foundation narratives of this kind will be prone to making a laughing stock of themselves rather than serving the Union's purposes.

The Union could be the first polity that adapts to the new conditions of today's postmodern existence of its citizens. It could renounce stories of shared values and historically situated commonality, and could, instead, take seriously its citizens' psychology. In practical terms, this is already the case. Just as citizen identity today is fleeting and varied, Union texts are fleeting and varied: they are complex, multi-layered, difficult to comprehend, subject to constant change, impacted in unpredictable ways by disordered cultural spaces and, in a bizarre way, floating. Citizen identity and the Union's gestalt converge in their shallowness. I do not mean this in a pejorative way. Shallowness is meant to denote the lack of anchors and roots and to describe the restless, adaptable project of a fast-paced, ever-transforming present. For both, the EU and its citizens, the hub of postmodern life strategy is not making identity stand, but the avoidance of being fixed and thus the fear of foreclosure of options. ${ }^{96}$ It is impossible to prophesy where such a conception of the political might lead. What we do know, though, is that the classical path of traditionally organized polities with their nation-state imagination of the political is not a viable option for the Union, as the helpless Commission initiatives have demonstrated. Europe's potential lies elsewhere, namely in the daring move to do without a constitution and all attendant pathos and patina. The Union would overcome the gap between the projected nature of the European polity on the one hand, which has appropriated cherished symbols of statehood and which lays claim to its citizens' political loyalty, and the nature of the European citizens' experience of citizenship on the other hand, which is dominated by rituals of trade, travel and consumption. Perhaps, by giving up its useless and implausible "A Citizen's Europe" discourse, it would gain a more reliable foundation for its claim to legitimacy, and be finally as "close to its citizens" as it strives to be.

\footnotetext{
${ }^{96}$ See supra note 22.
} 